\title{
Mechanical Behavior of Pillow Lavas in Mako Supergroup: Case of South Mako Hill
}

\author{
Déthié Sarr ${ }^{1}$, Meissa Fall ${ }^{1}$, Papa Malick Ngom², Mapathé Ndiaye ${ }^{1}$ \\ ${ }^{1}$ Laboratoire de Mécanique et Modélisation-UFR Sciences de l’Ingénieur, University of Thiès, Thiès, Senegal \\ ${ }^{2}$ Département de Géologie, FST-UCAD, Université Cheikh Anta Diop of Dakar, Dakar, Senegal \\ E-mail:dethie.sarr@ufrsi-thies.sn \\ Received July 9, 2011; revised August 24, 2011; accepted October 3, 2011
}

\begin{abstract}
This work shows the Kédougou-Kéniéba inlier (eastern Senegal) pillow lavas behavior from laboratory to field. Some uniaxial tests are carried out on five types of specimens of pillow lavas. These types of specimens are: microscopically healthy rock, fractured rock without filling, fractured rock filled with epidote, chlorite and calcite and rocks with tension crack filled with quartz. The Young moduli and the uniaxial compression strength are good for the healthy rock. The Young moduli fall slightly for facies with horizontal cracks while uniaxial compression strength $\left(R_{c}\right)$ varies slightly. For filled fractured specimens, $R_{c}$ and Young modulus (E) decrease remarkably. Decreases are most important for cracks filled with epidote, chlorite and calcite than with quartz. That is due to the differences of rigidity between these materials. Also, the slope stability of hillsides in this area depends on to these characteristics.
\end{abstract}

Keywords: Unconfined Compression Test-Uniaxial Compression Strength (UCT, $\mathrm{R}_{\mathrm{c}}$ ), JRC (Joint Roughness Coefficient), Young Modulus (E), Roughness, Kédougou-Kéniéba Inlier, Lineaments, Discontinuities, Dihedral, Slope, Hillside

\section{Introduction}

The Kédougou-Kéniéba inlier has long been subject of geological research and significant gold's reserves are found. Mains mining companies expand over and started the gold extraction. It therefore becomes necessary to know the rocks behaviors in this area. Basalts are mostly cases the mineralized host rock formations. Knowledge of the mechanical behavior of this rock became priority. The pillow lavas are the basaltic facies more represented in this area. It outcrops very well in this area with relatively the same geological characteristic. So we choose the Badian hill to conduct geomechanical studies on this specimen. This hill is crossed by a very dense network of fractures and tension cracks filled or not by secondary crystallization. Some of these discontinuities may be recognized in the field but for others, microscopic observations are necessary. In this paper, we will highlight the impact of these fillings on the rocks behaviors. The last paragraph of this paper consists to analysis of hillsides stabilities. For this, we are going to use the stereographic method.

\section{Geological and Geographical Context}

Proterozoic formations are located in the far south east of Senegal (Figure 1(e)). This area is crossed by the Gambia River and the Falémé (Senegal River flowing). It climate is soudano-sahelian. Birimian formations of eastern Senegal are localized in this inlier (Figures 1(a) and (b)) which is a portion of the West African Craton (Figures 1(c) and (d)). This inlier consists of paleoproterozoic formations surrounded by more recent formations (Upper Proterozoic). Bounded on west by the Mauritanides chains, in the east by the "Plateau Mandingue" and on south by the Medina Kouta basin, it subdivided in two Supergroups [1]:

- The Mako supergroup located in the west part of the inlier and dominated by volcanic formations. Many litho- stratigraphic models are given by various authors [2,5-11] to explain this volcanic domain.

- The Supergroup of Dialé-Daléma, which includes the old series of Dialé and Daléma defined by Bassot [1,2]. It represents the eastern area of the inlier and is dominated by sedimentary rock [1,2,12-14]. 

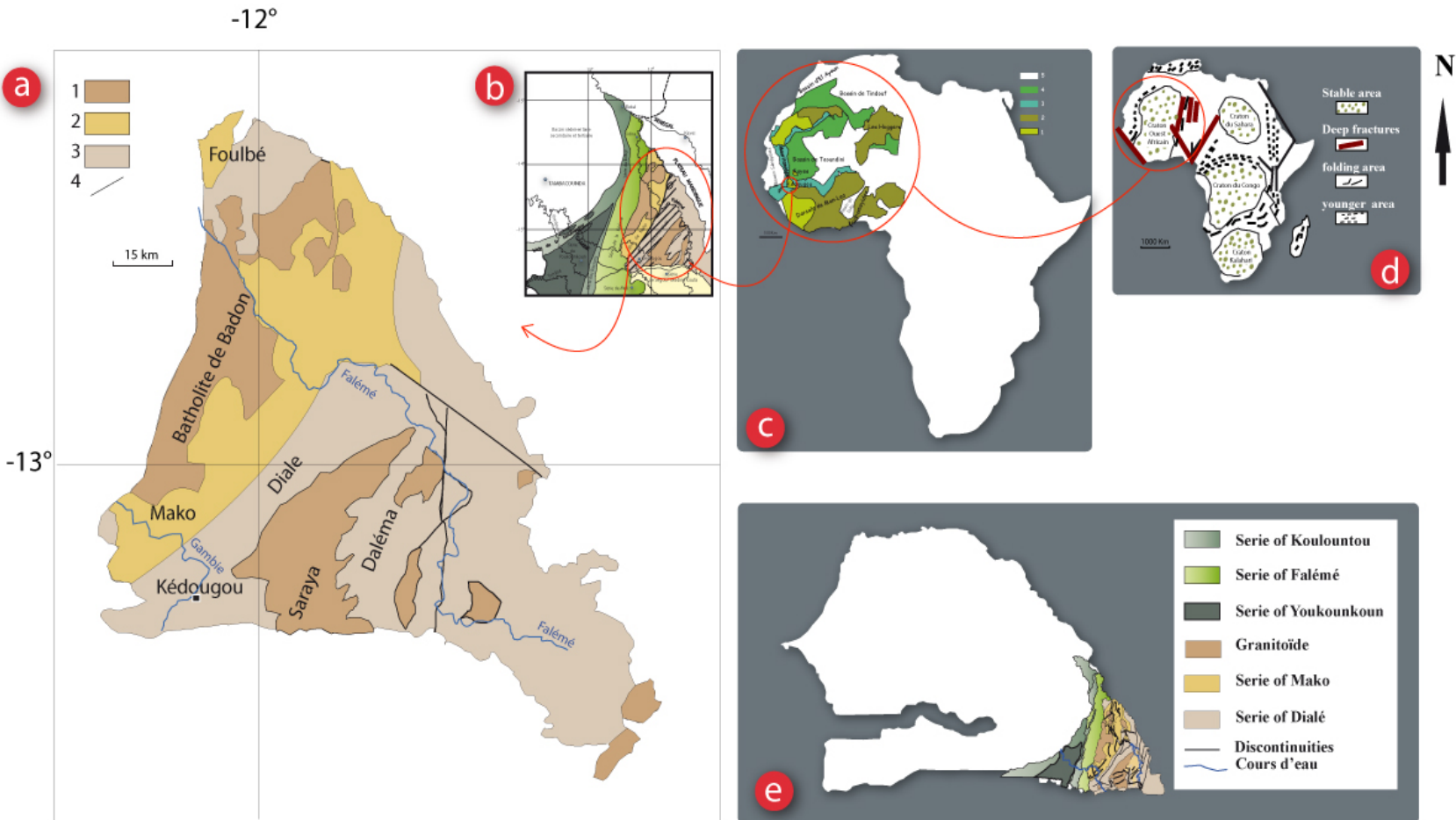

Figure 1. Kédougou-Kéniéba inlier in the African framework [2,3,4 modified] (a) Kédougou-Kéniéba inlier; (b) Eastern Senegal; (c) West African Craton; (d) African Cratons; (e) Location of Kédougou-Kéniéba inlier.

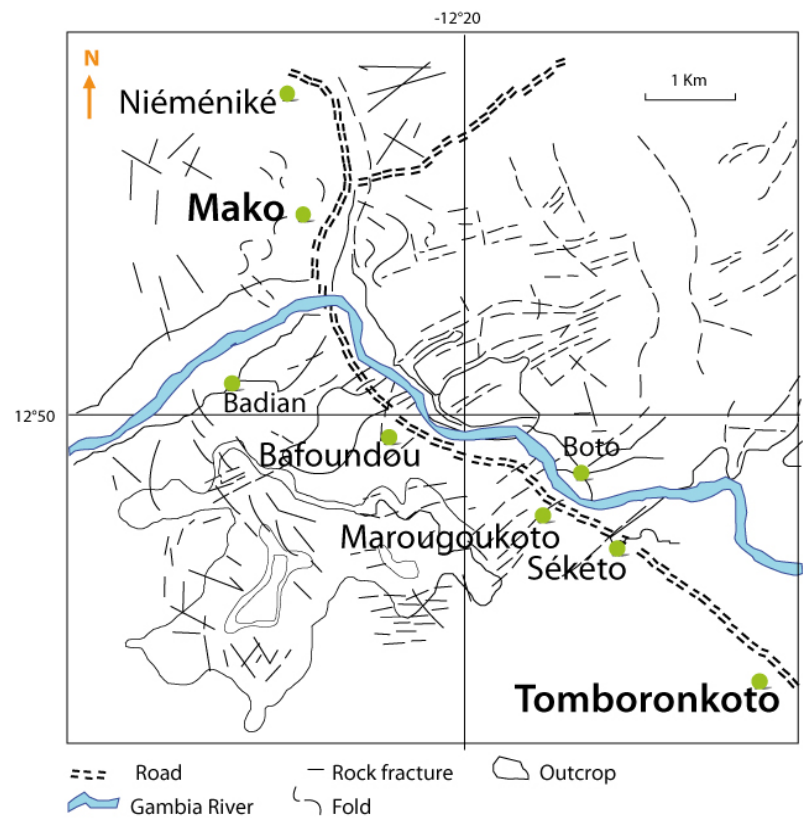

Figure 2. Map of lineaments of the sector.

\section{Mechanical Characterization}

\subsection{Field Data}

\subsubsection{Structural Data}

By this map, we can remark that the whole area is cross- ed by fracturations. In many cases, they appear like schistosity of fracture but in little case we can have a crenulated schistosity. It is the case in the rhyolitic tufs showing a microfolding. Orientations of fractures are NE-SW, N-S, NW-SE or approach to N-S and E-W axes. Socking are also identify in the north east of Mako (in the volcano-sedimentary rocks). Foldings are also presents under the form of straight folding and sometimes inclined and knee folds. For igneous rocks, folds can be remark after analyses of the schistosity of fractures or the orientation of the axe of pillow lavas.

Measurements of mechanical parameters are carried on the hill located on the interface of Badian-BafoundouMaragoukoto and data are regrouping by discontinuities affinities. So, these data make JRC, spacing and frequencies of discontinuities.

\subsubsection{JRC, Spacing, Frequencies and Opening of Discontinuities}

The JRC (Joint Roughness Coefficient) is estimated by comparing the profile of the discontinuities with Barton and Choubey charter [15-17]. It is given by the following relation where $J R C_{n}$ is the exact value, $\left(J R C_{0}\right)$ the reference value, $\left(L_{n}\right)$ the measured length and $\left(L_{0}\right)$ the reference length:

$$
J R C_{n}=J R C_{0}\left(\frac{L_{n}}{L_{0}}\right)^{-0,02 J R C_{0}}
$$


The spacing between discontinuities is defined by tracing a scaline and measuring the distance between different discontinuities. From these data, we deduce the spacing as the average distance between discontinuities. Frequency $(f)$ is defined by the following function where $X$ is the average distance:

$$
f=\frac{1}{X}
$$

Given the range of these $J R C$ (Table 1), we can see that we have smooth to slightly rough discontinuities. This more or less smooth aspect of the discontinuities confer them remarkable power of shear. So a small tangential strength can caused displacement of joint. However for filling discontinuities, filled materials confer them a greatest ability to resist to the strength. In fact, the units located on both sides of cracks are welded like a single entity. The filling materials are quartz, chlorite, calcite or epidote.

In the field where discontinuities are great extension, important sinuosities contribute to add the ability of the rock to resist shearing strength caused by the imbrications of the bloc.

The Table 2 show that spacing of discontinuities are very narrow to narrow for cracks, narrow for tension cracks and moderate for fractures according to the ISRM classification $[18,19]$. Openings of the discontinuities are variable. It varies from 7 to $15 \mu \mathrm{m}$ for micro discontinueties, 0.1 to 0.5 for cracks and 3 to $4 \mathrm{~cm}$ for tension cracks.

\subsection{Experimental Data}

\subsubsection{Petrographic Data}

Petrographic data on rocks and discontinuities are first

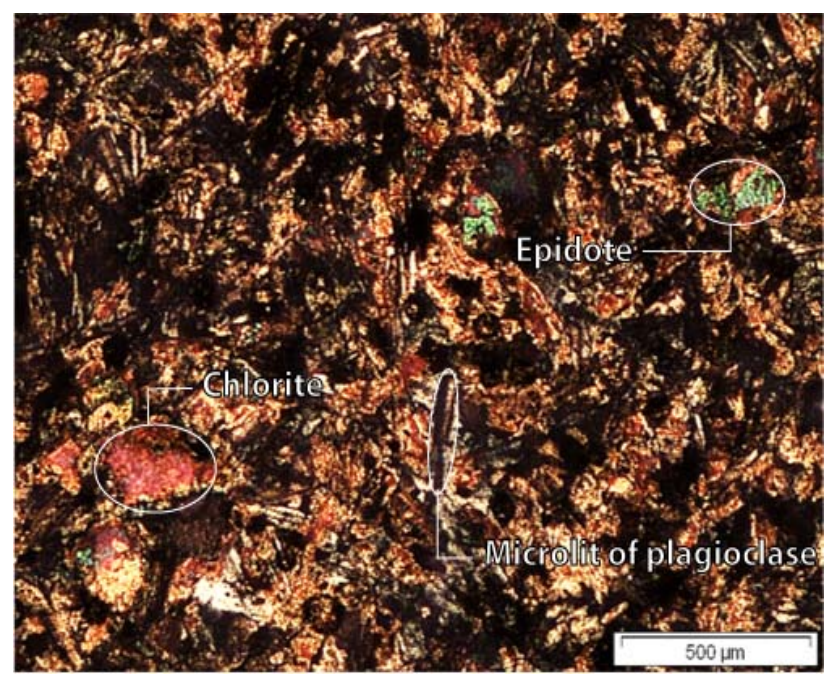

(a) defined on the field and then by microscoscopic observation. Samples were recovered on the hill. The field observations show that the hill is cross by a large set of tectonic structures. These pillow lavas show in microscopy, porphyric microlitic texture with microlite of plagioclase and included pyroxene (Figures 3(a) and (b)). The plagioclases show polysynthetic macle. These micro discontinuities are either tension cracks filled or unfilled fractures (Figure 4).

Table 1. Ranges JRC to discontinuities.

\begin{tabular}{cc}
\hline Type of Joint & JRC values \\
\hline Tension cracks & $3-4$ \\
Unfilled fractures & $2-5.2$ \\
Filled fractures & $1-3$ \\
Cracks & $0.5-1.5$ \\
\hline
\end{tabular}

Table 2. Ranges of variation of spacing and frequency.

\begin{tabular}{ccc}
\hline Type of joint & Spacing $(\mathrm{m})$ & Frequency \\
Tension cracks & $0.08-0.11$ & $9.1-12.5$ \\
Unfilled Fractures & $0.11-0.30$ & $3.3-9.1$ \\
Cracks & $0.02-0.11$ & $9.1-50$ \\
\hline
\end{tabular}

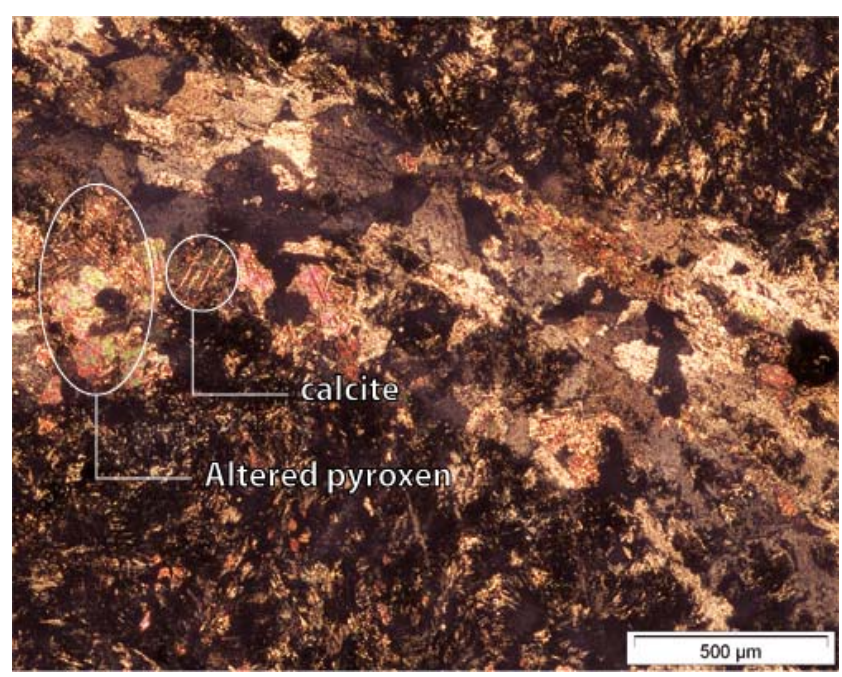

(b)

Figure 3. Identification of minerals on the basalt (3.a healthy rock; 3.b fractured rock). 
Some of these fractures are filled with white crystallization recognized in microscopic analyses as calcitic and epidotitic natures. Green crystallizations in the filonnets of rock are chlorite and epidote. Calcite can be recognized by it iridescent appearance. The surface of the preparation is dusty characteristic of the low metamorphism grade. The calcite, epidote and chlorite reflect metamorphism in the green schist facies and an initial composition of basalts rich in calcium. Veins and veinules reflect hydrothermalism.

\subsubsection{Devices and Experimental Procedure}

This device consists of a press type compression «Tinius Olsen» with capacity varying between $12 \mathrm{kN}$ to $600 \mathrm{kN}$ Depending on the material and experiences carried gauge will be chosen. So we used the gauge $300 \mathrm{kN}$. In this class, the ring of load includes major tick marks ranging from 10 to $10 \mathrm{kN}$ secondary and tertiary graduations are respectively 0.5 and $0.25 \mathrm{kN}$. The first step of the experimentation is to carry out a series of tests so as to choose the adapted loading speed to carry the test for a time greater than or equal to 5 minutes. Second step consists in applying gradually load to parallelepipedic samples. The specimen is placed between top and bottom plates of the press in such a way to ensure that loading speed is constant throughout the all test. The reading of stress and corresponding displacement is made every 45 second.

\subsubsection{Results and Discussions}

Analysis of different experimental curves of these basalts shows variations of Young's moduli and compressive strengths. The tests results are summarizing in Table 3.

Highest Young moduli are obtained with healthy basalts (Figure 5(a)) without visible discontinuities. Thus, the average modulus of the specimens is $13351 \mathrm{MPa}$. After, we have successively the modulus of unfilled discontinuities (Figure 5(b)), tension cracks and microcraks filled with quartz (Figure 5(c)), multidirectional cracks (Figure 5(d)) filled with calcite and epidote (Figure 5(e)). The Young moduli (MPa) are respectively 12566, 10300, 9833 and 6647. The highest uniaxial compressive strength are obtained for multidirectional cracks, followed by the filled cracks and the healthy rock with relative same value of uniaxiale compressive strength (85 and 86.7 $\mathrm{MPa}$ ) and the tensions cracks (75 MPa). The weaker facies is corresponding to crack-basalts filled with calcite and epidote (64.4 MPa).

These facts are due to of cracks present in the rock. Indeed, microscopic analysis shows that our basalts are micro-fractured. First, the mineralogy of these basalts shows microliths of plagioclases and porphyric pyroxenes transformed partially to epidote and chlorite. These micro-discontinuities affect mechanic parameters of the rock.

For healthy basalts microstructures not affect comparing other specimens the Young moduli. The microdiscontinuities are corresponding to macle, cleavage and veinlet present in rock can affect the Young modulus. These microdiscontinuities are also present to the other facies. But for the uniaxial compressive strength a lot of quantities of microfracturation limit the propagation of the fracturations.

The second facies with upper modulus is the unfilled cracks. For this facies, specimens are divided into two parts separate by the discontinuity plan. So, for carrying the test, we superpose the two parts. As these fracture have a certain roughness that ensure good adhesion of both parts and the load apply is normal, the fracturations affect the Young modulus of material. Thus, the characteristics involved in the variation of modulus are relatively same as the first sample.

In third, we have the tension cracks filled with quartz. Quartz is harder than other minerals of the rock. And this hardness of the quartz comparatively to plagioclase and pyroxene caused deviation of charge during the load and affect most pyroxene and plagioclase with micro discontinuities like macle and cleavage. This is felt also if the compressive strength is weak.

Table 3. Compression test results.

\begin{tabular}{lcc}
\hline \multicolumn{1}{c}{ Parameters } & E (MPa) & Rc (MPa) \\
\hline Healthy basalts & 13,351 & 85 \\
Unfilled fractures & 12,566 & 86.7 \\
$\begin{array}{l}\text { Tension cracks with quartz } \\
\text { Fractures filled with calcite and } \\
\text { epidote }\end{array}$ & 10,300 & 75 \\
Multiple fractures & 6647 & 64.4 \\
\hline
\end{tabular}

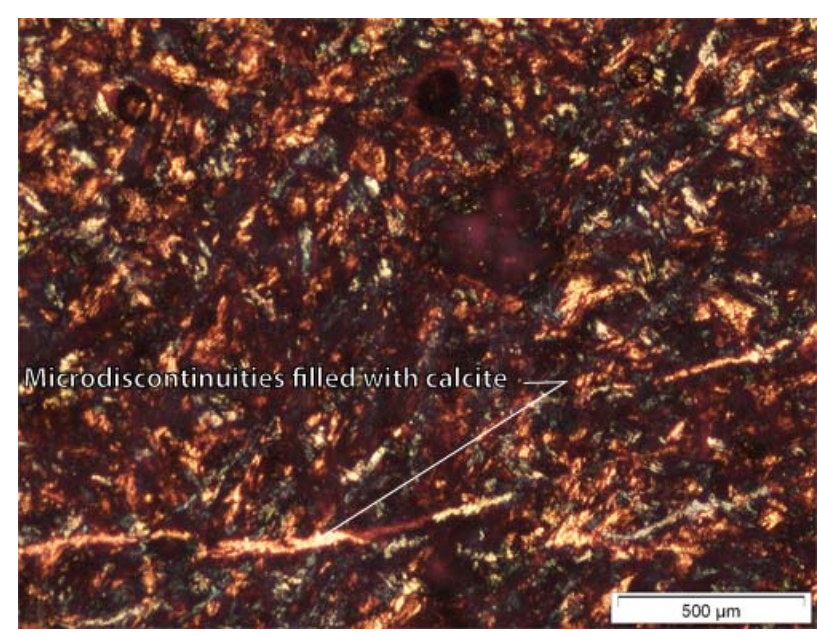

Figure 4. Microscopic appearance of discontinuities. 
(a). Healthy Pillow

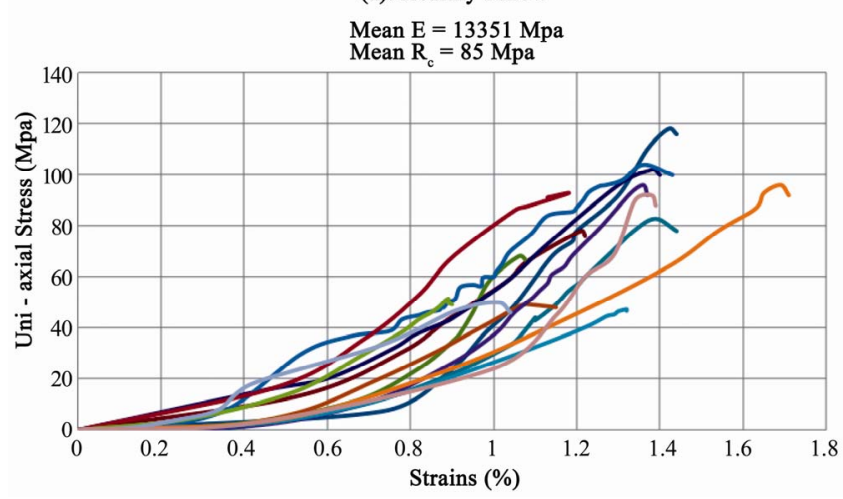

(a)

(c). Tension cracks filles with quartz

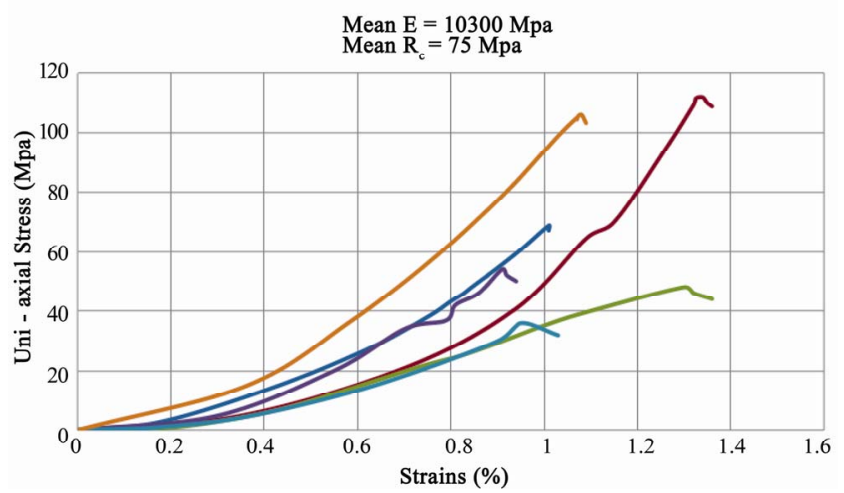

(c) (b). Pillow lavas with unfilled discontinuities

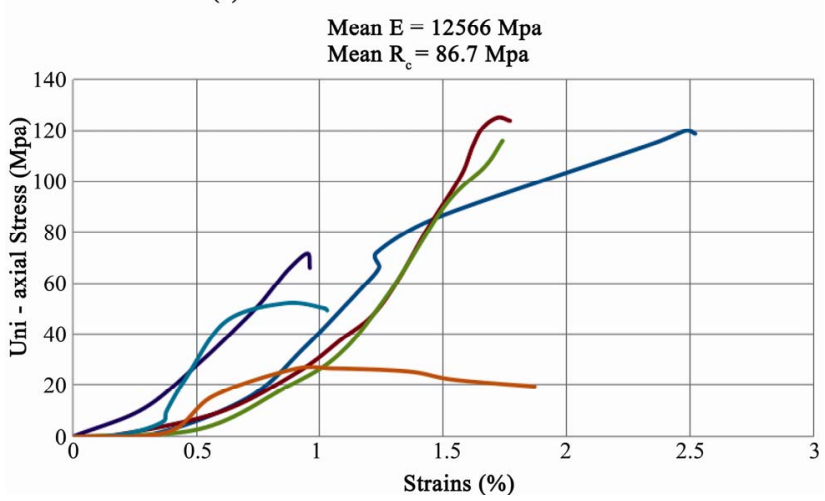

(b)

(d). multiple direction of cracks

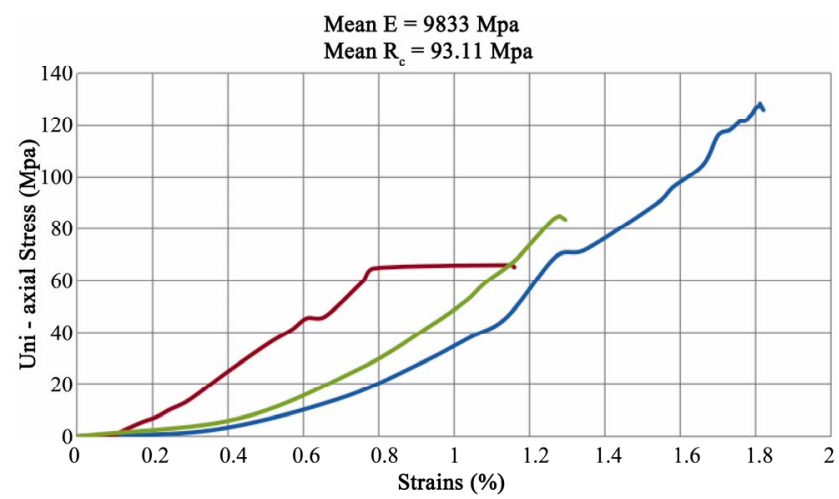

(d)

(e). Fractures filled with epidote, clacite and chlorite

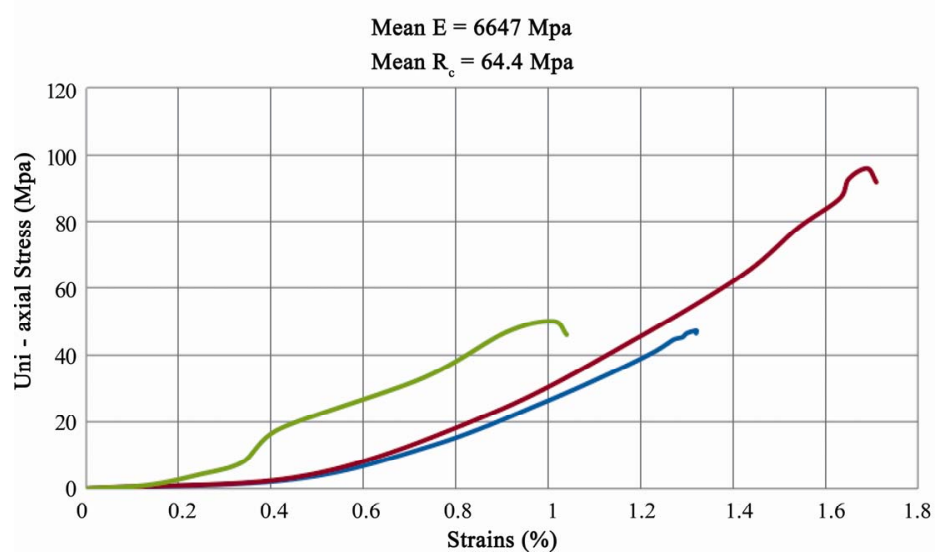

(d)

Figure 5. Stress-strain relations of Proterozoic pillow lavas.

Specimen with multiple cracks and variables fillings shows low Young modulus but greater than for the facies with epidote and calcite. This is the result of the trend balance between the quartz filling and epidote and calcite filling. In fact, the high quantity of discontinuities reduces remarkably the rigidity of the material. But the bifurcations caused by the micro discontinuities reduce the uni- axial compressive strength.

The specimen with a filling of calcite and epidote shows the lowest moduli of rigidity due to the differential rigidity between those minerals and the rock matrix composition. But, unlike the previous filling, in this case the materials filled the discontinuities are softer than the rock minerals. This will facilitate the reduction of the rigidity 
of the samples but also its very low compressive strengths.

The pillow lavas of Mako show the uniaxial compressive strength of healthy rock $\left(\mathrm{R}_{\mathrm{c}}\right)$ and unfilled crack rock (JCS) are substantially identical and the average is more or less most important for cracks unfilled rock than healthy rock. This is due to the presence of microfractures (photo 2) with most often opening of $15 \mu \mathrm{m}$ and the compression tests are realized on unaltered joints.

\section{Slope Stability of Hillsides of Collin}

\subsection{Analysis of Dips and Pole's Densities of Fractures}

An overall analysis shows that discontinuities are of variables dip (Figure 6) and diverse orientations given by density poles (Figure 7). The hillside Wassadou-Badian the density map shows an grouping of poles in focus area NE, SE, SW and NW with a higher concentration in NW and SW the dip direction is also variable but with most concentration from south to north when we go from Wassadou to Badian. In wake of Dalakoy (after Wassadou) we have two sides; the one is running between Wassadou and Dalakoy and the second is along the extension of Dalakoy from the hill. In the first hillside poles are concentered on NE, SE, NNE and ENE with low dips for discontinuities to NW, SW and SE. Concentrations of poles are oriented NNE-SSW and NWSE and orientations of discontinuities NE-SW and NNW-SSE and NESW. In the second hillside vergences are NNE, S, E, SE and SW. the hillside parallel to Badian-Bafoundou direction, poles are concentered on NW, NE, N and S area with low dip directions excepted the NW area with high dips. The left hillside of shows poles densities grouped on a great circle $\mathrm{N}-\mathrm{S}$ with little concentrations on SE with low dips excepted dips on SE. These dips are on all directions.

\subsection{Stability of the Hillsides}

This section studies the possibility of sliding of rocks by stereographic method. For this, all fracturations crossed are represented in a stereogram. So, for this analysis, we must have the orientation of the hillside and of the bedrock. On the case of this area, the bedrock is favorable to the sliding for all hillsides.

For the stability analysis of hillsides representing in these it is necessary to consider "pierced" of plans forming dihedral angle, the "meet" of the intersection between those plans and the bedrock and the "release" of one of plans constitute dihedral. While the bedrock is in all our cases favorable, the "meet" is always verify.

The hillsides are representing by green great circle and blue is the direction of sliding. Others colors represent the discontinuities. So, in our stereographic representations, Figure 8 (a) shows possibility of sliding along lines of intersection of plans formed dihedral angles to the NNE and NNW directions but Figure 8 (b) represents possibilities of sliding along the intersection associate to a possibility of sliding along one of the two plans consisting the dihedral to the NNW. In Figure 8(c), we have also possibilities of sliding along the line of intersection to NW and SW and sliding along one of the two plans to WSW. Figures 8(d) and (e) show only sliding along line to NW and in Figure 8(f) we have the same behavior but to NW and SSW. In Figure 8(j) that sliding has done to NW and WSW. Figure 8(h) shows sliding along lines to NNW, ENE and ESE, and sliding along one plan to NE and E. Figure 8(i) shows sliding along the lines of intersection and one of planes formed dihedral to all the area located from E to SSW. For hillside of Figure 8(i), we have some slide to $\mathrm{E}$ and $\mathrm{S}$ along lines and to SE along one of the planes. The Figure $\mathbf{8}(\mathbf{k})$ shows possibilities of sliding to S SSE and SSW.

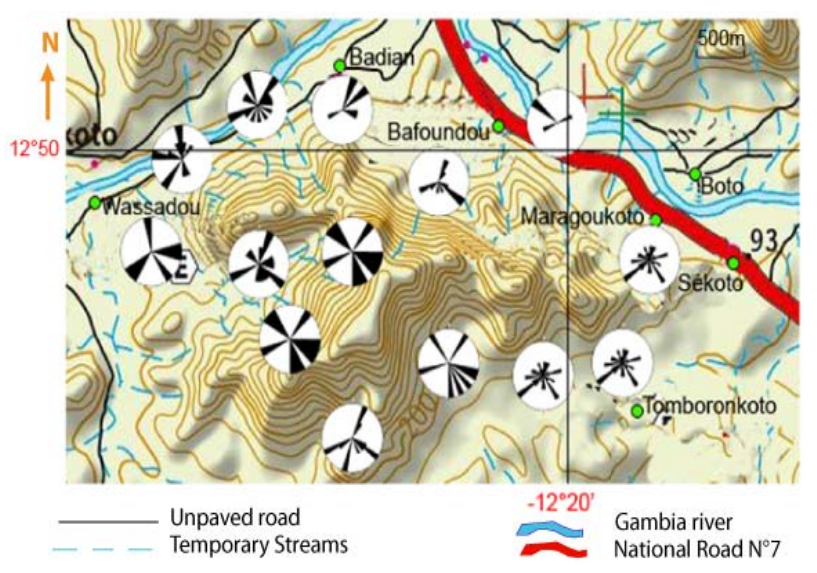

Figure 6. Dip directions map of discontinuities.

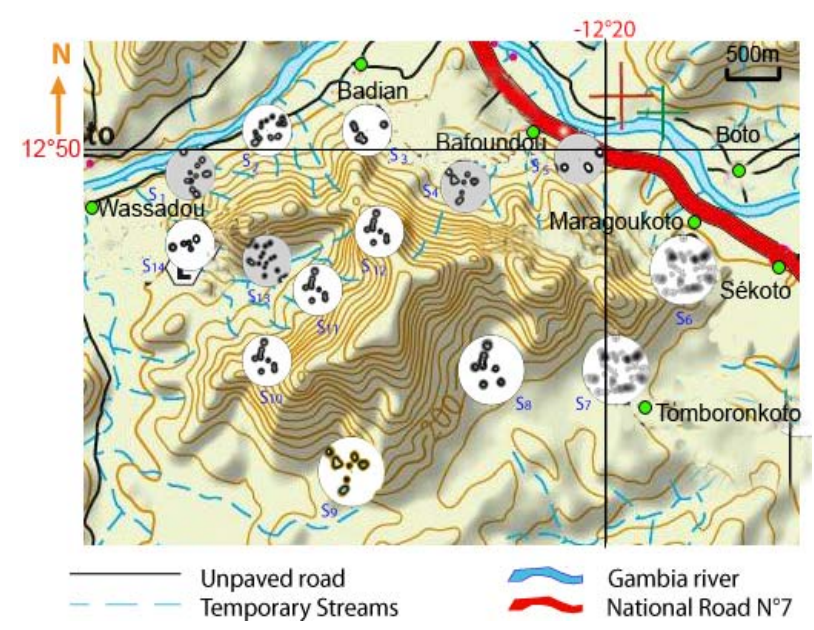

Figure 7. Densities diagram map of discontinuities. 


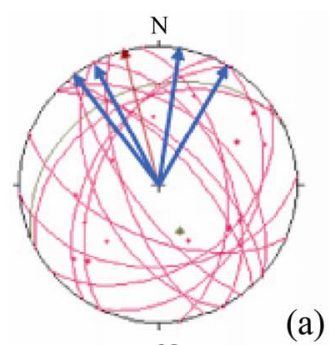

(a)

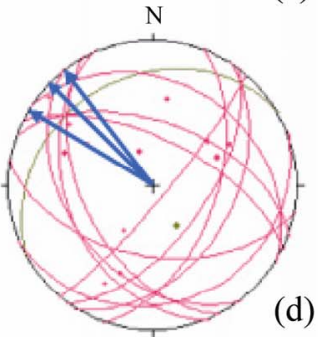

(d)
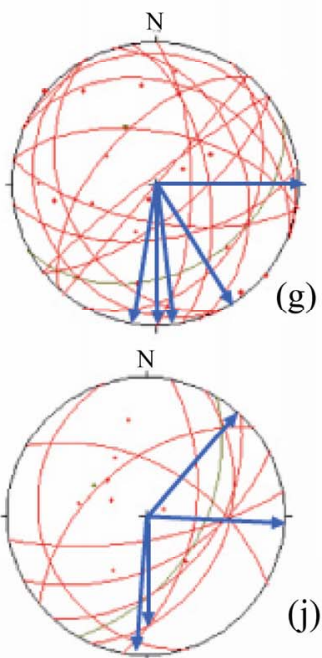

(j)

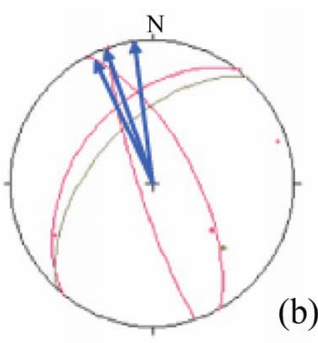

(b)
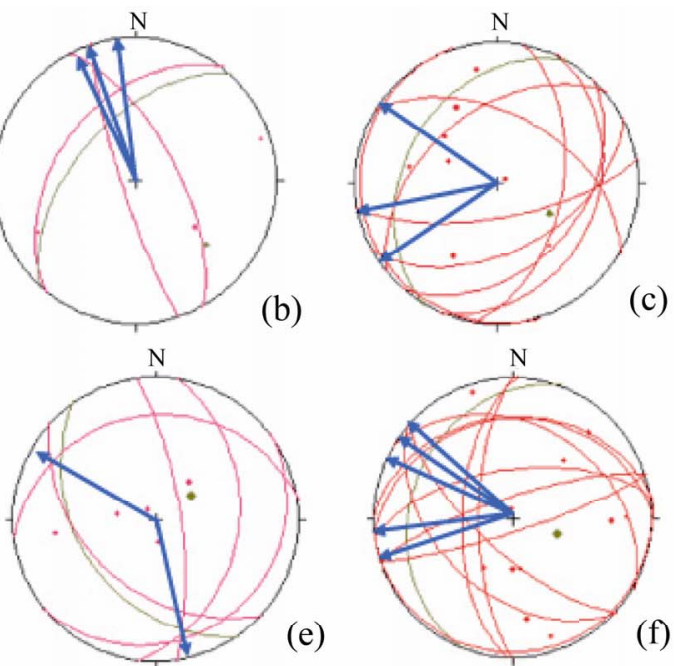

(f)

Figure 8. Stereographic plots of discontinuities cross on different hillsides.

\section{Conclusions}

Previous studies allow us to conclude that the area of Mako is characterized by discontinuities and microdiscontinuities oriented N-S, E-W, NE, NNE, NW and NNW. It is brittle discontinuities (fractures) and ductile discontinuities (folds). The hill of Badian shows like others formations of the domains the same discontinuities. A finest study of this hill show fractured and microfractured and microfractured unfilled or filled with calcite, epidote and quartz. The spacing of the discontinuities are moderate that is causing block rarely metric. The mechanical behavior of this rock is also influenced by the presence of imperfection. Thus, the application of normal charge on a discontinuity makes decrease the Young modulus but the compressive uniaxial strength varies only slightly. If the discontinuity of the rock is filled, the basalts behavior will depend to the nature of filling. Quartz significantly decreases the Young's modulus and uniaxial compressive strength. But the reduction of the characteristic of the rock is more important when the material is filled by epidote and chlorite. But if the specimen contains 3 or 4 direction of discontinuities the Young's modulus decreases while the compressive uniaxial strength increase.

This hill shows a complex instability with plane sliding associate to a sliding along the line of intersection between two planes that formed dihedral angles.

\section{Acknowledgements}

Authors would like to Acknowledge Mr. Amsata Thiam, technical Director of SENBUS industries sa for his great contribution in this work, allowing as to us the supplies of his manufactory for the samplings. Acknowledge also to Dr. Edmond Dioh, Head of the Department of Geology of the IFAN-Cheikh Anta Diop (Dakar), most of the mi- 
croscopic analysis had been done in his laboratory. The authors would like to acknowledge Mouhamadou Lamine Lo (Assistant Professor-EPT/Thiès) for his guidance and valuable input in this research project.

\section{References}

[1] J. P. Bassot, "Etude Géologique du Sénégal Oriental et de ses Confins Guinéo-Maliens, ” Thèse Doctorat és Science de la terre, Université de Clermont Ferrand, Clermont 115 pages.

[2] J. P. Bassot, "Etude géologique du Sénégal oriental et ses et ses confins Guinée-Maliens,” Mémoire BRGM, 1966, 40 pages.

[3] G. Rocci, "Essai d'Interprétation des Measures Géochronologique,” La Structure de l'ouest Africain. Science de la Terre, Vol. 10, No. 3-4, 1965, p. 461.

[4] N. Clauer, R. Caby, D. Jeanette and R. Trompette, “Geochronological of Sedimentary and Metasedimentary precambrian Rock of the West African Craton,” Precambrian Research, Vol. 18, No. 1-2, 1982, pp. 53-71.

[5] J. P. Bassot, "le Complexe Volcano-Plutonique CalcoAlcalin de la Rivière Daléma (Est Sénégal): Discution de sa Signification Géodynamique dans le cadre de l'Orogenèse Éburnéenne (Protérozoique inférieur), 1987.

[6] A. Dia, "Caractères et Significations des Complexes Magmatiques et Métamorphiques du Secteur de Sandikounda —Laminia (Nord de la Boutonnière de Kédougou-Kéniéba, Est du Sénégal)," Un Modèle Géodynamique du Birimien de l'Afrique de l'Ouest, Thèse d'Etat, Université de Dakar, 350 pages.

[7] P. M. Ngom, “Contribution à l'étude de la Série Birimiennes de Mako Dans le Secteur Aurifère de Sabodala (Sénégal Oriental),” Thèse de Doctorat du 3e Cycle, Université de Nancy I., 1985, 134 pages.

[8] D. P. Diallo, “Caractérisation d'une portion de croûte d’Âge Protérozoïque Inférieur du Craton Ouest Africain: Cas de l'Encaissant des Granitoïdes Dans le Supergroupe de Mako (Boutonnière de Kédougou),” Implications Géodynamiques. Thèse d'Etat, Université Cheikh Anta Diop de Dakar, 1994, 466 pages.

[9] P. M. Ngom, "Caractérisation de la Croûte Birimienne dans les Parties Centrale et Méridionale du Supergroupe de Mako,” Implications Géochimiques et Pétrogénétiques,
Thèse d'Etat Université Cheikh Anta Diop de Daka, 1995, 240 pages.

[10] E. Dioh, "Caractérisation, Signification et Origine des Formations Birimiennes Encaissantes du Granite de Diombalou (Partie Septentrionale de la Boutonnière de Kédougou-Sénégal oriental),” Thèse d'Etat, Université Cheikh Anta, Diop de Dakar, Sénégal, 1995, 447 pages.

[11] S. Cissokho, "Etude Géologique du Secteur de Mako (Partie Méridionale du Supergroupe de Mako, Boutonnière de Kédougou—Kéniéba, Sénégal Oriental): Implication sur la Diversité Magmatique,” Thèse de 3e cycle, Université Cheikh Anta Diop de Dakar, 2010, 214 pages.

[12] Bassot J. P. et Caen Vachette, "Données Géochronologiques, Géochimiques Nouvelles sur les Granitoides de l'Est du Sénégal: Implication dans l'Histoire Géologique du Birrimien de Cette Region,” African Geology Edition, 1984.

[13] P. M. Ndiaye, "Etude Géologique et Métallogénique de la Partie Septentrionale du Granite de Saraya: Secteurs de Missi ra, Wassangara, Frandi. Sénégal Oriental,” Thèse Doctorat du 3ème Cycle Université Cheikh Anta Diop Dakar, 1986, 109 pages.

[14] P. M. Nidaye, "Evolution au Protérozoïque Inférieur de la Région Est Saraya, Supergroupe de Dialé-Daléma Sénégal Oriental: Tourmalinisation, Altérations Hydrothermales et Minéralisations Associées,” Thèse d’Etat Université Cheikh Anta Diop de Dakar, 1994, 372 pages.

[15] N. Barton and V. Choubey, "The Shear Strength of Rock Joints in Theory and Practice,” Rock Mechanics and Rock Engineering, Vol. 10, No. 2, 1977, pp. 1-54.

[16] M. J. A. Leal-Gomes, "Some New Essential Questions about Scale Effects on the Mechanics of Rock Mass Joints," South African Institute of Mining and Metallurgy, International Society for Rock Mechanics 10th Congress Technology Roadmap for Rock Mechanics, Vol. 2, 2008.

[17] Jaboyedoff, “Caractérisations Géométriques Simples des Discontinuités dans un Massif Rocheux,” Quanterra, International Independent Center of Climate Change Impact on Natural Risk Analysis in Mountains Area, 13 pages.

[18] Zhao, "Propriétés des discontinuités EPFL-ENAC- LMR," 2008, 94 pages.

[19] ISRM, “Technology Roadmap for Rock Mechanics,” South African Institute of Mining and Metallurgy, Johannesburg, 2003. 